\title{
Xenophobia before and after the Paris 2015 Attacks. Evidence from a Natural Experiment
}

\author{
Sebastian Jungkunz ${ }^{1}$, Marc Helbling ${ }^{1}$ \& Carsten Schwemmer ${ }^{1}$ \\ Otto-Friedrich-University Bamberg ${ }^{1}$, Feldkirchenstraße 21, 96052 Bamberg, Germany \\ E-Mail for correspondence: sebastian.jungkunz@uni-bamberg.de
}

\author{
14.11.2017
}

Accepted for publication in journal "Ethnicities"

\begin{abstract}
:
In light of ongoing debates that discuss the link between Muslim migration and terrorist attacks in various European cities, this paper investigates how attitudes toward (Muslim) immigrants have been affected by these attacks. We draw on a German student survey conducted immediately before and after the attacks in Paris in November 2015. The experimental vignette design allows us to further differentiate between attitudes toward Syrian migrants from different religious backgrounds. We show that the attitudes towards immigration held by students who identify with conservative parties became more negative after the attacks. Immigrants' religion also plays an important role depending on whether the issue in question is a social or political one. The attitudes of liberal students are hardly affected. This paper goes beyond existing studies that only measure attitudes in the aftermath of such attacks and focuses on attitudes regarding policy responses to terrorist attacks or attitudes towards immigrants in general. We show that such attacks do not lead to negative attitudes in general; they mostly do so for people who attach great importance to issues of national security. We also see that people differentiate between various migrant groups.
\end{abstract}

Key words: terrorism, threat, religion, Muslims, party identification, survey experiment 


\section{Introduction}

Over the last 15 years, there have been several Islamist terrorist attacks around the world, which have not only led to many deaths but also to heated debates about Islam and Muslim immigration in the Western world. In light of these controversies, it has become important to study the effects of terrorist attacks on public opinion - not only in the places where attacks occur and among the people directly affected, but also in other places, because these incidents are seen as general attacks against the Western world that could occur anywhere at any time.

Measuring the effects of terrorist attacks is notoriously difficult, as researchers have typically not asked comparable questions before and after the events. Furthermore, many studies investigating the effects of terrorist attacks have focused on how people position themselves in relation to certain policy responses (e.g. Huddy et al., 2005: 595; Kam and Kinder, 2007; Malhotra and Popp, 2012). Few studies, however, have focused on attitudes towards the group (in this case Muslims) that is regarded by some as directly related to terrorism or have differentiated between attitudes towards different groups (e.g. Davis, 2007).

To overcome the limitations of existing studies, we analyse attitudes towards Syrian migrants based on a German student survey that was conducted in two rounds immediately before and after the attacks in Paris in November 2015. Our full factorial 
survey design additionally allows us to differentiate between attitudes towards Muslim and Christian migrants.

Our findings show that, on average, students are not particularly affected by the attacks. The students whose attitudes become more hostile in the aftermath are primarily those who identify with right-wing parties that are very much concerned with issues of national security and that have long warned about the negative consequences of Muslim immigration (and who do so even more directly after the attacks). Moreover, we show that these hostilities are primarily directed against Muslim (and not Christian) immigrants and thus that clear differentiations between different migrant groups are made.

\section{Threat perception}

The literature on xenophobia has shown that perceived threat is one of the most important factors explaining negative attitudes toward immigrants (Huddy et al., 2005). For instance, people support actions that reduce the power or presence of the group that is perceived as a threat (Stephan and Stephan, 2000). Surveys have shown that more than two thirds of Americans felt depressed after the attacks on 11 September 2001 and more than one third indicated that they tried to avoid exposure to terrorism by changing their everyday behaviour around others because they were concerned that they or their family members could become victims of terrorism (Huddy et al., 2002: 422f.). 
These effects were even found for those not directly affected by terrorism; they identified with the victims and experienced increased distress (Hobfoll et al., 2008). We also see evidence of this increased concern in the media coverage of such incidents: terrorist attacks in Western countries are covered more extensively than deadlier attacks outside the Western world (see also Fischhoff et al., 2003). If such events happen within a person's (cultural) environment or affect people he or she knows or identifies with, this gives rise to feelings of vulnerability and calls positive world views into question (Canetti-Nisim et al., 2009; Huddy et al., 2005: 595). Davis (2007) has, for example, shown that, in cases where people feel personally threatened by terrorist attacks, they feel even more threatened when their own country is being attacked. In addition, Duckitt and Fisher (2003: 202) proposed that threats towards an individual's world view could result in a change in interpretation of beliefs regarding the nature of social realities, thus creating a need for authority and social control. In contrast to anxiety, which leads to risk-averse behaviour, threat gives rise to an urge for vengeance. It strengthens intolerance and negative prejudice, regardless of whether there is an actual threatening external force or simply a perceived feeling of threat (Huddy et al., 2005: 593f.). Effectively, threatened group resources will then lead to growing prejudice against the threatening out-group (Morrison et al., 2009: 205).

Further, we know that threat reduces cognitive functioning and simplifies thinking (Eysenck, 1992; Wilder, 1993). A threat might thus appear greater than it actually is 
(Lerner and Keltner, 2001). At the same time, simplification can lead to more categorybased thinking and activate ethnocentrism (Kam and Kinder, 2007: 333). Terrorist attacks have greatly affected public discourse about immigration and security throughout the last two decades and have made these issues much more salient (Dolezal et al., 2010: 12). As a consequence, average citizens have been made aware of a potential threat seemingly originating from immigrants in general or from certain immigrant groups in particular (see also Legewie, 2013: 1204). If the aggressors are clearly identified as acting in the name of Islam, people belonging to that religion might be specifically perceived as a threat (Piazza, 2015). Davis (2007: 211ff.) has shown that threat perceptions mainly affected groups that were thought to be related to terrorist attacks (see also Brooks and Manza, 2013: 115ff.). People are thus likely to respond to perceived threat by expressing an epistemic and existential need for closure (Kruglanski, 1989) and terror management (e.g. Greenberg et al., 1986) as well as by engaging in ideological rationalization through system justification (Jost and Banaji, 1994), which might lead them to adopt a more conservative mindset (Jost et al., 2003). In light of terrorist attacks, citizens are hence likely to show a greater degree of authoritarianism, which translates into political conservatism, racial prejudice and ultimately support for right-wing parties (Bonanno and Jost, 2006; Echebarria-Echabe and Fernández-Guede, 2006: 263).

In sum, we expect sympathy for immigrants from countries linked to the Paris terrorists as well as support for favourable legislation for such groups to decline after the attacks. 
Further, we expect approval to decline even more when citizens are confronted with immigrants who share the same religion (Islam) as the attackers.

\section{Party identification}

Political parties play a particular role in politicizing immigration issues in general and terrorist events in particular. This role has become increasingly important over the last two decades, with immigration becoming one of the most polarizing issues in the electoral arena (Kriesi et al., 2012). Immigration has become a favourite topic for populist rightwing parties, which can be said to 'own' this issue (Mudde, 2007). In addition, individual perceptions are also heavily influenced by the arguments of political actors or, more generally, by public debates (Boomgaarden and Vliegenthart, 2007, 2009; Hopkins, 2010, 2011; Walgrave and Swert, 2004).

The Paris attacks occurred during a period of extremely heated debates on refugee inflows in Germany and on the question of Islamization in particular (Häusler, 2016). While parties on the left and right of the political spectrum had been debating migration issues for quite some time, these issues became even more important after the autumn of 2015 due to the rise of right-wing populist movements and parties such as Pegida (Patriotic Europeans Against the Islamization of the West) and the AfD (Alternative for Germany), which highly politicized these issues (Dostal, 2015). Moreover, in the aftermath of the 
Paris terrorist attacks, these actors also intensively linked the incidents to the ongoing influx of Muslim refugees.

Previous research has shown that the impact of terrorist attacks on individual attitudes depends largely on party identification (PID). As such, people on the right oppose outside groups more strongly after terrorist attacks, as they are more sensitive to threats to personal or national security (Peffley et al., 2015: 820). Confirming this argument, Merolla and Zechmeister (2009) found that authoritarians became even more intolerant after being exposed to terrorist threats. Party identification can also be seen as incorporating a variety of constructs that interact with citizens' attitudes (Campbell et al., 1960). People acquire preferences for particular parties based on their individual personality traits, basic personal values and social backgrounds - i.e. based on characteristics predominantly present throughout their process of socialization. Hence, a high degree of openness will make a person more likely to support a progressive liberal left-wing party (Schoen and Schumann, 2007). People with personalities that are structured by rigid thinking, resistance to change and a closed-minded belief system are instead more likely to belong to the conservative political camp. Core political values, such as equality or adhering to law and order, are in turn manifested in basic personal values like universalism or security and conformity (Schwartz et al., 2014). Internalization throughout the process of socialization will thus make citizens look for political parties that will provide policies that accord with their personal needs. Last but 
not least, homogeneous social characteristics in terms of education, class and income also promote the development of a coherent identification with a political party that approximates an individual's needs (Lazarsfeld et al., 1944). A specific combination of these traits, values and contexts will then trigger corresponding responses towards immigrants as well (Dinesen et al., 2016; Vecchione et al., 2012). For conservatives, a massive wave of immigration will likely tap into their need for security and a stable social and political system (Caprara et al., 2006). As a result, party identification can be regarded as the attitudinal point where dispositions and goals converge. The PID thus acts as a proxy that incorporates all of these aspects, making one's political affiliation a mirror of one's personal characteristics.

Yet party identification doesn't just reflect citizens' internal nature, but also incorporates their exposure to political communication (Zaller, 1992). As citizens are quite impression-driven when forming attitudes, elite cues play a central role in shaping opinion dynamics, thus pointing to the public's limited cognitive resources (Lodge et al., 1989; Zaller and Feldman, 1992). Through such cues, political elites offer an interpretation of the current socio-political environment, thereby trying to connect value principles and political issues within day-to-day politics (Goren, 2005: 895; Schoen, 2006: 96). As can be seen in the aftermath of $9 / 11$, citizens are quite likely to adhere to their party's position when it comes to combating terrorism (Rattinger et al., 2016). The same applies to migration issues (Boomgaarden and Vliegenthart, 2009), especially in the 
heated public discourse in 2015 (Dostal, 2015). Partisans can therefore be seen as favouring both a party's long-term principles as well as its immediate policy solutions. To conclude, we expect that party identification played a vital role in shaping citizens' attitudes toward immigrants in the wake of the Paris attacks. First, conservatives should have generally shown less affection for immigrants. Second, conservatives should have reacted more strongly to the attacks. Finally, we expect to see a stronger reaction from conservatives when confronted with Muslim immigrants, since these immigrants share the same religion as the attackers, who represent an immediate threat; effectively, this means Muslim immigrants constitute an out-group of potential scapegoats.

\section{Data and design}

We conducted a quasi-experimental survey that contained a randomly assigned vignette treatment before and after the Paris shootings on 13 November 2015. The first round of our experimental survey was conducted between 13 October and 2 November. The participants were BA students of political science from the University of Bamberg. 65 students filled in the online questionnaire in class or at home. With the Paris attacks occurring right after the survey, we opted to draw a second cross-sectional sample immediately afterwards. The same questionnaire was sent out via several university mailing lists in Germany. The questionnaires of the second round were submitted between November 20 and 26, roughly between one and two weeks after the attacks. ${ }^{1}$ Altogether, 
71 per cent of the 157 students participating across both rounds are from Bamberg. For our analyses, we excluded all respondents who indicated that they were no longer students; these are most likely academic staff members, ranging from research assistants to professors. Excluding this group of respondents did not change our findings, as can be seen in the robustness checks, where we used a control sample that combined students and non-students (see appendix C).

In order to analyse attitudes towards immigration, we randomly assigned respondents to one of four versions of the following introductory text (see Figure 1; for detailed question wordings see appendix A):

Figure 1: Introductory text with treatment

The first part of this study is about your attitudes toward immigrants from Syria that are currently active in social and political life in Germany. For the following questions, imagine a group of [Christian]/[Muslim] immigrants from Syria who [seldom or never]/[regularly] go to [church]/[mosque] and [seldom or never]/[regularly] pray at home.

The words in brackets were changed randomly across the four treatment groups and referred to non-religious Christians, non-religious Muslims, religious Christians and religious Muslims. We thus have a full factorial design that manipulates religious affiliation and the religiosity of an immigrant group from Syria. We selected a group of 
immigrants $^{2}$ that was highly politicized during the period of our survey and that came from a country in which both Muslims and Christians live.

After being asked whether they would allow members of this group to hold public rallies and demonstrations to ensure better recognition of group interests in Germany, respondents were asked to indicate their general feelings toward these groups and to state their level of agreement with three statements on social and political rights for these immigrant groups on a five-point scale (see Table 1; variables were recoded so that high values stand for positive attitudes):

Table 1: Question wording of dependent variables

\begin{tabular}{|l|l|}
\hline Feelings & $\begin{array}{l}\text { Now we would like to know what your general feelings are about this } \\
\text { group. We would like you to rate them with a feeling thermometer. } \\
\text { Ratings between 50 and } 100 \text { degrees indicate that you feel favourably } \\
\text { and warm toward them. Ratings between 0 and 50 degrees indicate } \\
\text { that you do not feel favourably toward them and that you do not care } \\
\text { too much for them. If you feel neither warm nor cold toward them, you } \\
\text { would rate them at 50 degrees. }\end{array}$ \\
\hline $\begin{array}{l}\text { Social } \\
\text { Welfare }\end{array}$ & $\begin{array}{l}\text { Imagine a single mother from this group with two children is } \\
\text { unemployed. To what extent do you agree with the statement that this } \\
\text { mother should receive social welfare benefits? }\end{array}$ \\
\hline Voting & $\begin{array}{l}\text { To what extent do you agree with the statement that members of this } \\
\text { group should be allowed to vote in national elections? }\end{array}$ \\
\hline Public Office & $\begin{array}{l}\text { To what extent do you agree with the statement that the members of } \\
\text { this group should be allowed to hold public office? }\end{array}$ \\
\hline
\end{tabular}


Respondents' party identification was recoded into a dummy for either liberal (0) or conservative parties (1). The liberal parties were the Social Democratic Party (SPD), The Greens (Die Grünen), The Left (Die Linke) and the Pirate Party (Piratenpartei). The conservative parties are the Christian Democratic Union (CDU), the Christian Social Union (CSU), the Free Democratic Party (FDP) and the Alternative for Germany (AfD). ${ }^{3}$ A small number of respondents did not provide information on their party identification. In these cases, we used party voting intentions as PID indicators instead. A minority of respondents $(n=3)$ did not state their voting intention either; in such cases we used their left-right self-identification. Excluding those respondents from the analysis did not alter the results in a significant way. Dummy variables were also created for the survey round ( $0=$ before Paris, $1=$ after Paris) and for the group membership treatment $(0=$ Christian, 1=Muslim). The $2 \times 2 \times 2$ design thus draws distinctions based on time (before/after the attack $)^{4}$, treatment (Christian/Muslim) and PID (liberal/conservative). This approach enabled us to make statements on the links between terrorist attacks and discrimination against immigrants of various religious backgrounds at the same time. Descriptive statistics for all variables are shown in

\section{Table 2.}


Table 2: Descriptive Statistics

\begin{tabular}{lcccc}
\hline & mean & sd & Min & $\max$ \\
\hline Round: After Paris & .570 & .497 & 0 & 1 \\
Treatment: Muslim & .437 & .498 & 0 & 1 \\
PID: Conservative & .238 & .428 & 0 & 1 \\
Feelings & 74.139 & 19.670 & 10 & 100 \\
Social Welfare & 4.573 & .797 & 1 & 5 \\
Voting & 3.673 & 1.333 & 1 & 5 \\
Public Office & 4.027 & 1.147 & 1 & 5 \\
$N$ & 151 & & & \\
\hline
\end{tabular}

\section{Results}

Full regression models of our analysis can be found in appendix B. As we used three-way interactions in our models and the interpretation of coefficients is very complex in this setting, we point the readers to Figure 2 for a graphical display of our findings. ${ }^{5}$ The graphs show attitudes toward the immigrant groups in general (feeling) and toward their social and political rights (welfare, voting, public office). In each graph, we identify whether a respondent received the Muslim or a Christian immigrant vignette and whether he or she identifies with a liberal or conservative party (two-way interaction effects). For each of these four respondent groups, we then indicate the mean values before and after the Paris attacks (three-way interaction effects). Our analyses show that religiosity has no 
effect, but that religious affiliation does. ${ }^{6}$ For this reason we focus on the perception of Muslim and Christian immigrants in our analyses.

Figure 2: Predicted values for student sample

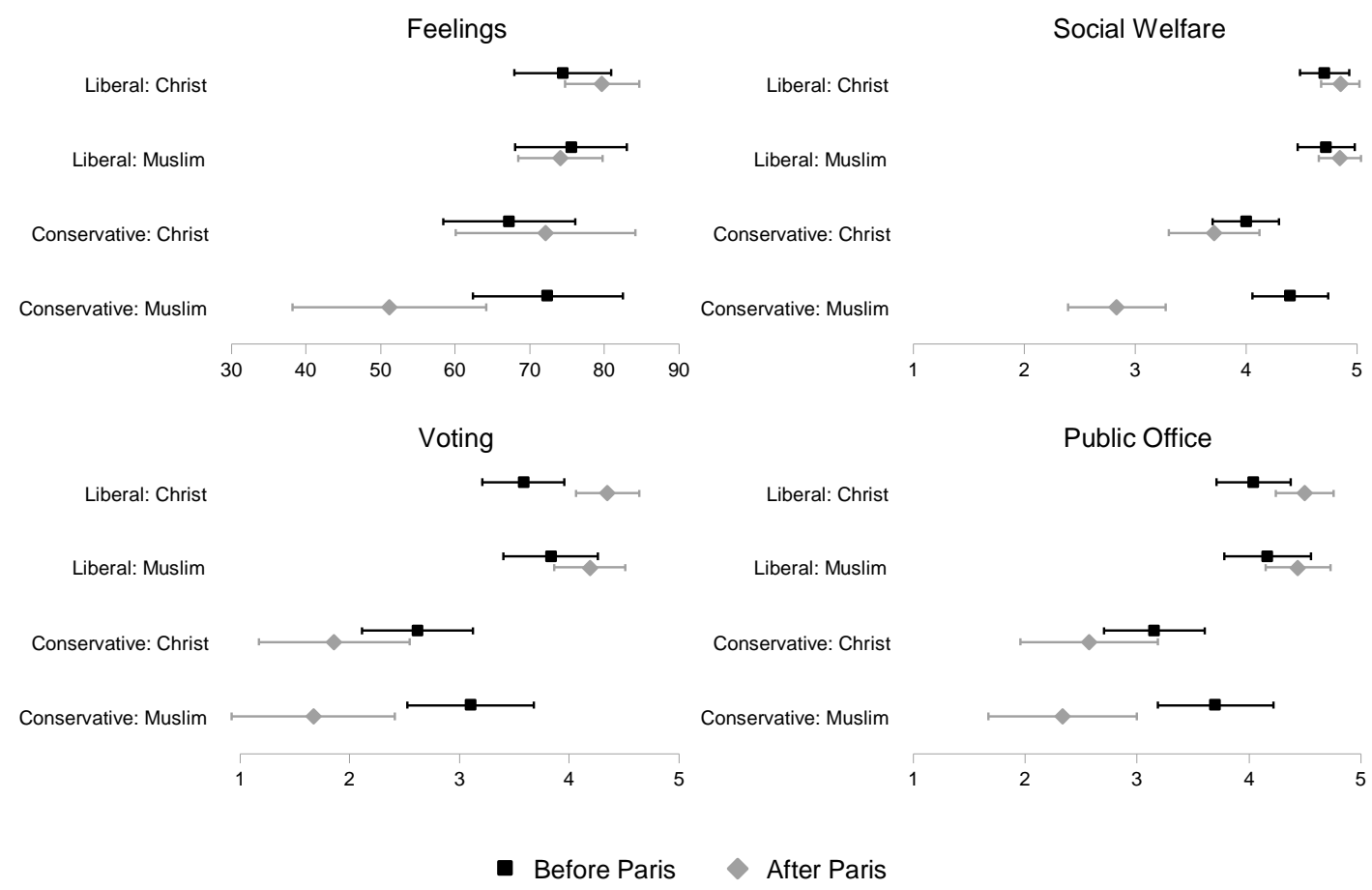

The figure shows mean values with $90 \%$ confidence intervals based on regression analyses.

Overall, the Paris attacks do not seem to have left a lasting imprint on prevailing opinion among German students per se (see also appendix B). In none of our four models did respondents differ significantly in their stance towards immigrants and their rights across time. The same applies to our stimuli relating to the religion of the immigrant in question. 
Attitudes seem to be structured along party identification lines instead, with conservatives showing a greater aversion toward Syrian immigrants and policies that address their social and political rights.

Yet this general pattern changes when we look at the potential interplay between covariates (see Figure 2). For general feelings and social welfare, the attacks affected public opinion only if conservatives were presented with a Muslim immigrant. None of the other combinations seem to have caused a change in opinion at all. Accordingly, liberals seemed to have rather warm feelings - of around 75 degrees - for both Christian and Muslim immigrants, both before and after the attacks. Conservatives presented with a Christian immigrant also exhibited predominantly favourable feelings. However, when confronted with the out-group responsible for the attacks, conservatives' sentiments dropped to around 50 degrees in the second round. This change may be related to the massive bias in media coverage on Islamist terrorist attacks (Kearns et al., 2017).

Even though the effect is only significant in the control sample, which includes both students and non-students (see robustness checks in appendix C), the shift of more than 20 percentage points is quite substantial. Moreover, the same effect appears for attitudes towards social welfare for immigrants. Again, liberals were almost unanimously in favour of supporting social welfare benefits for a single immigrant mother across time, regardless of whether she was Christian or Muslim. Conservatives, on the other hand, 
seemed reluctant to support the immigrant mother after the attacks if she was described as a Muslim.

Regarding political integration, the reaction of the public seems to have changed as well. Once again, there was no dramatic shift among liberals across time. If anything, they became somewhat more sympathetic towards immigrants after the attacks. Conservatives, on the other hand, showed the opposite behaviour after Paris. Whereas they were once somewhat indecisive, they were now opposed to further political integration of immigrants, regardless of religion. For instance, conservatives presented with a Muslim frame exhibited substantially lower levels of support for voting rights from a neutral standpoint of 3.2 before the attacks to disagreement of 1.7 afterwards. The results for those with a Christian frame are similar but slightly less considerable. What is more, liberals and conservatives moved in opposite direction as a consequence of the attacks. The coping strategies for such a tragic occurrence thus seem contrary. This is also confirmed by Sobolewska, Ford and Sniderman (2016), who found that citizens with liberal and authoritarian outlooks became increasingly polarized after the Paris attacks, and by Peffley and colleagues (2015: 829), who found a stronger polarization between left- and right-wingers in Israel after various attacks.

Liberals seem to perceive a need for further political integration of immigrants in order for them to be a part of society. By contrast, conservatives adopt a much more hawkish position on immigration affairs when they feel threatened. Their internal need for 
structure, order and security prompts them to avoid the unfamiliar. Even worse, as conservatives regard immigrants (especially Muslims) as an out-group per se, but also attach the stigma of the attacks to them, there is a decline in sympathy rates for integration policies as well.

Now, although this explains the pattern for the Muslim frame, it does not help us understand why conservatives react differently in the Christian frame, depending on whether they are dealing with social (feelings and welfare) or political issues (voting and public office). Most likely, conservatives are simply not willing to grant civic rights to immigrants irrespective of their religion. Previous research has shown that right-wing self-identification leads to more restrictive national identities (e.g. Citrin and Sides, 2008). Given that nowadays (especially national-level) voting rights are the lone important rights that remain exclusively reserved for citizens, it can be assumed that people with restrictive concepts of national identity are particularly opposed to this idea. Thus, while it is nationality that shapes conservatives' attitudes towards political rights, when it comes to social issues, opinion is largely influenced by the religion of the immigrant in question. The Paris attacks hence triggered a rise in negative sentiments, since the subsequent media coverage revealed that the threat came from Muslim perpetrators. Arguably, it is immigrants' most obvious characteristics that guide conservatives' opinions. Whereas in daily life or social affairs, religious beliefs are thought to be the most salient feature, nationality is the dominant characteristic when it 
comes to political rights. As a result, we see different patterns of reaction depending on context and stimuli.

\section{Discussion and Conclusion}

Our results show that terrorist attacks do not have an overall negative effect on attitudes towards (Muslim) immigrants. Instead it appears that it is party identification, or the personal characteristics behind it, that affects how immigrants are perceived. Conservatives already resented immigrants slightly more than liberals before the attacks and became even more negative afterwards. Such reactions were in turn highly dependent upon the religion of immigrants and whether respondents were asked about their general feelings or their attitudes towards social and political rights. It thus proved useful to make such differentiations.

The question remains to what extent we can generalize our findings to other contexts and populations. Student samples are not always very different from general population samples, especially regarding political variables (Druckman and Kam, 2011: 51ff). And indeed, other studies with representative samples have found similar effects to our study in different contexts (Legewie, 2013; Peffley et al., 2015; Sobolewska et al., 2016). In any case, our sample can be assumed to be somewhat atypical, as it is composed of individuals that are rather insensitive to terrorist attacks. Most respondents in our sample 
are students, who can be expected to have more liberal values than the average German citizen (Flanagan and Lee, 2003; Iser and Schmidt, 2003). In other words, we should expect to find even more substantial results in a representative sample that includes citizens with less tolerant attitudes (Kam et al., 2007: 420f.). Further advantages of our sample over other studies include the timing of the study and the conceptualization of the relevant phenomena. For researchers seeking to guarantee external validity, these aspects are at least as important as the sample itself (Druckman and Kam, 2011). We collected data right before and after the attacks and are in a position to differentiate between attitudes toward different migrant groups. In addition, we are looking at the reaction of German students to a terrorist attack in a neighbouring country. We would expect even larger effects if the attack had happened within Germany. One could argue that the levels of sympathy with the victims in Paris and of anxiety due to terrorist attacks also depends on where people live and how close they are to the site of the attacks, physically or psychologically. Thus, it is possible that French people would show stronger affection for the victims, but also that people from major cities like Berlin would feel closer to those affected than people from the rural areas of France, either because they feel more connected to their cosmopolitan lifestyle or simply because they are more likely to become potential victims themselves. In order to rule out such self-selection effects and potential composition differences between both rounds and universities, we checked respondents' motivations for participating in the survey. Yet neither interest in politics 
nor being threatened by terrorism or refugees seemed to vary substantially between groups. There were also no striking differences between the Bamberg students across both rounds, as well as between students from different universities in the second round. ${ }^{7}$ This means that there was no variation in motivation depending on city size as well.

Finally, we expect effects for party identification to be similar for terrorist attacks in general, as conservatives have a stronger need for security and a stable socio-political environment (Huddy and Feldman, 2011). These needs should become even stronger when Muslims or immigrants are involved, since this coincides with their more Manichean perceptions of politics and society in times of threat (Westen, 2007). Further, a single instance of terrorism, however massive it is, is quite distinct from chronic terrorism (Spilerman and Stecklov, 2009: 183f.). The attacks in New York City, London, Madrid, Paris and Berlin are therefore completely different in nature from what citizens suffered in Northern Ireland and Israel for decades. Whereas the former is far beyond the normal range of experience for citizens and does not require a change of their concept of normality and coping strategies, the latter kind leaves lasting imprints on society. Depending on the social context, this will likely lead to a polarizing of society in which existing cleavages are reinforced; yet, if society is cohesive citizens will show solidarity by confronting the common threat (Spilerman and Stecklov, 2009: 184). Even though there is evidence that the initial direct effects of terrorism like stress spikes and sharp decreases in tolerance are rather short-lived, indirect and long-lasting effects are possible 
and likely; however, we lack further research on this issue. In particular, future scholars need to address when and how politicians use such fear to push through certain policies (Lupia and Menning, 2009: 103). Lastly, it would also be interesting to see how the results presented here compare with other external shocks like ecological catastrophes.

What we can take away from this is that terrorist attacks do not have uniform effects on public opinion per se. Citizens never react the same way as a result of an external shock. More than anything else, it is individual traits and personal values, like openness and security guidance that prompt people to draw different conclusions.

\footnotetext{
${ }^{1}$ Two questionnaires were submitted later on 1 December and 7 December. We cannot rule out for certain that respondents from the first round also participated in the second round, even though we asked them to participate only once. Nevertheless, the total number of such respondents should be negligible and since they are distributed randomly across treatment groups this should not affect our results.

${ }^{2}$ Even though the literal English translation of the questionnaire refers to 'immigrants', it is quite certain that German citizens associate Syrian refugees with the term due to the heated public discourse in the country at that time.

${ }^{3}$ A negligible number of respondents stated affiliation with or voting intentions for minor parties in an open-ended question format. As such, references to 'the Communists', the ecological-democratic party (ÖDP) and Die Partei were coded as liberal, while references to the Freie Wähler (FW) and Neue Liberale were coded as conservative.

${ }^{4}$ Since the samples of our two rounds differ, we can make inferences only in the aggregate.
} 
${ }^{5}$ Due to our limited sample size, we report $90 \%$ confidence intervals instead of the conventional $95 \%$. Regardless of statistical significance, our results show several effects of substantial importance. Figures were generated with the Stata scheme plotplain (Bischof 2017).

${ }^{6}$ This confirms results from Helbling and Traunmüller (2016), who differentiate between non-religious, religious and also fundamentalist immigrants. They mostly found differences between fundamentalists and other migrants but hardly any effects between non-religious and religious migrants. In our experiment we included only descriptions of non-religious and religious immigrants.

${ }^{7}$ The lone exception is that students from Bamberg seemed to be slightly more threatened by refugees than non-Bamberg students in the second round (see appendix D). 


\section{Appendix}

\section{A. Items for treatment and dependent variables}

\section{$\underline{\text { Treatment }}$}

German original:

Im Folgenden geht es uns um Ihre Einstellung bezüglich Einwanderern aus Syrien, die derzeit aktiv am sozialen und politischen Leben in der BRD beteiligt sind. Stellen Sie sich für die folgenden Fragen eine Gruppe [christlicher]/[muslimischer] Einwanderer aus Syrien vor, die [regelmäßig]/[selten oder nie] eine Kirche aufsuchen und [regelmäßig]/[selten oder nie] zu Hause beten.

English translation:

The first part of this study is about your attitudes toward immigrants from Syria that are currently active in social and political life in Germany. For the following questions, imagine a group of [Christian]/[Muslim] immigrants from Syria who [seldom or never]/[regularly] go to [church]/[mosque] and [seldom or never]/[regularly] pray at home.

\section{Dependent variable - Feelings}

Scale: 0 [cold feelings] - 100 [warm feelings]

\section{German:}

Jetzt würden wir gerne mehr über ihre allgemeine Gemütslage zu dieser Gruppe erfahren. Wir möchten Sie bitten, diese über ein Gefühlsthermometer einzuordnen. Bewertungen zwischen 50 und 100 Grad auf dem Thermometer bedeuten, dass Sie der Gruppe positiv und warm gegenüber stehen. Bewertungen zwischen 0 und 50 Grad bedeuten dass Sie der Gruppe negativ gegenüberstehen und sich nicht besonders für diese interessieren. Falls Sie weder warme noch kalte Gefühle für die Gruppe empfinden, würden Sie Ihre Gemütslage mit 50 Grad bewerten.

English translation:

Now we would like to know what your general feelings are about this group. We would like you to rate them with a feeling thermometer. Ratings between 50 and 100 degrees indicate that you feel favourably and warm toward them. Ratings between 0 and 50 degrees indicate that you do not feel favourably toward them and that you do not care too much for them. If you feel neither warm nor cold toward them, you would rate them at 50 degrees. 


\section{Dependent variable - Social Welfare}

Scale: 1 [completely disagree] - 5 [completely agree]

German:

Nehmen Sie an, eine alleinerziehende Mutter mit zwei Kindern aus dieser Gruppe ist arbeitslos. Inwieweit würden Sie der Aussage zustimmen, dass diese Mutter Sozialhilfeleistungen empfangen sollte.

English translation:

Imagine a single mother from this group with two children is unemployed. To what extent do you agree with the statement that this mother should receive social welfare benefits?

\section{$\underline{\text { Dependent variable - Voting rights }}$}

Scale: 1 [completely disagree] - 5 [completely agree]

\section{German:}

Inwieweit stimmen Sie der Aussage zu, dass es Mitgliedern dieser Gruppe erlaubt sein sollte ihre Stimme für nationale Wahlen abzugeben?

English translation:

To what extent do you agree with the statement that members of this group should be allowed to vote in national elections?

\section{Dependent variable - Public Office}

Scale: 1 [completely disagree] - 5 [completely agree]

German:

Inwieweit stimmen Sie der Aussage zu, dass es Mitgliedern dieser Gruppe gestattet sein sollte, öffentliche Ämter auszuüben?

English translation:

To what extent do you agree with the statement that the members of this group should be allowed to hold public office? 


\section{B. Nested models}

Table 3: Full regression models (students)

\begin{tabular}{|c|c|c|c|c|}
\hline & Feelings & Social Welfare & Voting & Public Office \\
\hline Round: After Paris & $\begin{array}{l}5.291 \\
(4.94)\end{array}$ & $\begin{array}{l}0.142 \\
(0.17)\end{array}$ & $\begin{array}{c}0.767^{* * * *} \\
(0.28)\end{array}$ & $\begin{array}{l}0.458^{*} \\
(0.25)\end{array}$ \\
\hline Treatment: Muslim & $\begin{array}{l}1.139 \\
(6.00)\end{array}$ & $\begin{array}{l}0.014 \\
(0.20)\end{array}$ & $\begin{array}{l}0.250 \\
(0.34)\end{array}$ & $\begin{array}{l}0.125 \\
(0.31)\end{array}$ \\
\hline PID: Conservative & $\begin{array}{l}-7.186 \\
(6.62)\end{array}$ & $\begin{array}{c}-0.708^{* * *} \\
(0.22)\end{array}$ & $\begin{array}{c}-0.968^{* *} \\
(0.38)\end{array}$ & $\begin{array}{c}-0.888^{* * *} \\
(0.34)\end{array}$ \\
\hline After Paris $*$ Conservative & $\begin{array}{l}-0.379 \\
(10.28)\end{array}$ & $\begin{array}{l}-0.427 \\
(0.35)\end{array}$ & $\begin{array}{c}-1.525^{* *} \\
(0.59)\end{array}$ & $\begin{array}{c}-1.041^{*} \\
(0.53)\end{array}$ \\
\hline After Paris * Muslim & $\begin{array}{l}-6.752 \\
(7.52)\end{array}$ & $\begin{array}{l}-0.020 \\
(0.26)\end{array}$ & $\begin{array}{l}-0.413 \\
(0.43)\end{array}$ & $\begin{array}{l}-0.187 \\
(0.39)\end{array}$ \\
\hline Conservative $*$ Muslim & $\begin{array}{c}4.030 \\
(10.07)\end{array}$ & $\begin{array}{l}0.386 \\
(0.34)\end{array}$ & $\begin{array}{l}0.235 \\
(0.58)\end{array}$ & $\begin{array}{l}0.421 \\
(0.52)\end{array}$ \\
\hline $\begin{array}{l}\text { After Paris * Conservative * } \\
\text { Muslim }\end{array}$ & $\begin{array}{r}-19.393 \\
(15.38)\end{array}$ & $\begin{array}{l}-1.261^{* *} \\
(0.52)\end{array}$ & $\begin{array}{l}-0.263 \\
(0.88)\end{array}$ & $\begin{array}{l}-0.597 \\
(0.79)\end{array}$ \\
\hline Constant & $\begin{array}{c}74.417^{* * *} \\
(3.93) \\
\end{array}$ & $\begin{array}{l}4.708^{* * *} \\
(0.13)\end{array}$ & $\begin{array}{c}3.583^{* * *} \\
(0.22) \\
\end{array}$ & $\begin{array}{c}4.042^{* * *} \\
(0.20) \\
\end{array}$ \\
\hline Observations & 151 & 150 & 150 & 150 \\
\hline$R^{2}$ & 0.089 & 0.361 & 0.349 & 0.295 \\
\hline
\end{tabular}


Table 4: Nested regression models of feeling thermometer

\begin{tabular}{|c|c|c|c|c|}
\hline & Base Model & $\begin{array}{l}\text { Interaction: } \\
\text { PID }\end{array}$ & $\begin{array}{l}\text { Interaction: } \\
\text { Treatment }\end{array}$ & Full Model \\
\hline Round: After Paris & $\begin{array}{l}0.167 \\
(3.28)\end{array}$ & $\begin{array}{l}2.375 \\
(3.75)\end{array}$ & $\begin{array}{l}4.792 \\
(4.28)\end{array}$ & $\begin{array}{l}5.291 \\
(4.94)\end{array}$ \\
\hline Treatment: Muslim & $\begin{array}{l}-3.466 \\
(3.18)\end{array}$ & $\begin{array}{l}-3.439 \\
(3.17)\end{array}$ & $\begin{array}{l}2.591 \\
(4.82)\end{array}$ & $\begin{array}{l}1.139 \\
(6.00)\end{array}$ \\
\hline PID: Conservative & $\begin{array}{c}-9.368^{* *} \\
(3.81)\end{array}$ & $\begin{array}{l}-5.405 \\
(5.02)\end{array}$ & $\begin{array}{c}-9.344^{* *} \\
(3.78)\end{array}$ & $\begin{array}{c}-7.186 \\
(6.62)\end{array}$ \\
\hline After Paris * Conservative & & $\begin{array}{l}-9.300 \\
(7.68)\end{array}$ & & $\begin{array}{c}-0.379 \\
(10.28)\end{array}$ \\
\hline After Paris * Muslim & & & $\begin{array}{c}-10.609^{*} \\
(6.38)\end{array}$ & $\begin{array}{l}-6.752 \\
(7.52)\end{array}$ \\
\hline Conservative $*$ Muslim & & & & $\begin{array}{c}4.030 \\
(10.07)\end{array}$ \\
\hline $\begin{array}{l}\text { After Paris * Conservative * } \\
\text { Muslim }\end{array}$ & & & & $\begin{array}{l}-19.393 \\
(15.38)\end{array}$ \\
\hline Constant & $\begin{array}{c}77.792^{* * *} \\
(3.07)\end{array}$ & $\begin{array}{c}76.378^{* * *} \\
(3.28) \\
\end{array}$ & $\begin{array}{c}75.175^{* * *} \\
(3.43)\end{array}$ & $\begin{array}{c}74.417^{* * *} \\
(3.93) \\
\end{array}$ \\
\hline Observations & 151 & 151 & 151 & 151 \\
\hline$R^{2}$ & 0.050 & 0.059 & 0.068 & 0.089 \\
\hline Adjusted $R^{2}$ & 0.030 & 0.034 & 0.042 & 0.044 \\
\hline
\end{tabular}


Table 5: Nested regression models of social welfare

\begin{tabular}{|c|c|c|c|c|}
\hline & Base Model & $\begin{array}{l}\text { Interaction: } \\
\text { PID }\end{array}$ & $\begin{array}{r}\text { Interaction: } \\
\text { Treatment }\end{array}$ & Full Model \\
\hline Round: After Paris & $\begin{array}{l}-0.105 \\
(0.12)\end{array}$ & $\begin{array}{l}0.133 \\
(0.13)\end{array}$ & $\begin{array}{l}0.026 \\
(0.15)\end{array}$ & $\begin{array}{l}0.142 \\
(0.17)\end{array}$ \\
\hline Treatment: Muslim & $\begin{array}{l}-0.017 \\
(0.11)\end{array}$ & $\begin{array}{l}-0.015 \\
(0.11)\end{array}$ & $\begin{array}{l}0.153 \\
(0.17)\end{array}$ & $\begin{array}{l}0.014 \\
(0.20)\end{array}$ \\
\hline PID: Conservative & $\begin{array}{c}-0.965^{* * *} \\
(0.14)\end{array}$ & $\begin{array}{c}-0.540^{* * *} \\
(0.17)\end{array}$ & $\begin{array}{c}-0.965^{* * *} \\
(0.14)\end{array}$ & $\begin{array}{l}-0.708^{* * *} \\
(0.22)\end{array}$ \\
\hline After Paris * Conservative & & $\begin{array}{c}-0.999^{* * *} \\
(0.26)\end{array}$ & & $\begin{array}{l}-0.427 \\
(0.35)\end{array}$ \\
\hline After Paris * Muslim & & & $\begin{array}{l}-0.299 \\
(0.23)\end{array}$ & $\begin{array}{l}-0.020 \\
(0.26)\end{array}$ \\
\hline Conservative $*$ Muslim & & & & $\begin{array}{l}0.386 \\
(0.34)\end{array}$ \\
\hline $\begin{array}{l}\text { After Paris * Conservative * } \\
\text { Muslim }\end{array}$ & & & & $\begin{array}{c}-1.261^{* *} \\
(0.52)\end{array}$ \\
\hline Constant & $\begin{array}{c}4.872^{* * *} \\
(0.11) \\
\end{array}$ & $\begin{array}{c}4.721^{* * *} \\
(0.11) \\
\end{array}$ & $\begin{array}{c}4.799^{* * *} \\
(0.12) \\
\end{array}$ & $\begin{array}{c}4.708^{* * *} \\
(0.13) \\
\end{array}$ \\
\hline Observations & 150 & 150 & 150 & 150 \\
\hline$R^{2}$ & 0.258 & 0.325 & 0.267 & 0.361 \\
\hline Adjusted $R^{2}$ & 0.243 & 0.306 & 0.246 & 0.329 \\
\hline
\end{tabular}


Table 6: Nested regression models of voting rights

\begin{tabular}{|c|c|c|c|c|}
\hline & Base Model & $\begin{array}{l}\text { Interaction: } \\
\text { PID }\end{array}$ & $\begin{array}{l}\text { Interaction: } \\
\text { Treatment }\end{array}$ & Full Model \\
\hline Round: After Paris & $\begin{array}{l}0.194 \\
(0.19)\end{array}$ & $\begin{array}{l}0.587^{* * *} \\
(0.21)\end{array}$ & $\begin{array}{l}0.419 \\
(0.26)\end{array}$ & $\begin{array}{c}0.767^{* * *} \\
(0.28)\end{array}$ \\
\hline Treatment: Muslim & $\begin{array}{l}0.046 \\
(0.19)\end{array}$ & $\begin{array}{l}0.049 \\
(0.18)\end{array}$ & $\begin{array}{l}0.337 \\
(0.29)\end{array}$ & $\begin{array}{l}0.250 \\
(0.34)\end{array}$ \\
\hline PID: Conservative & $\begin{array}{c}-1.565^{* * *} \\
(0.23)\end{array}$ & $\begin{array}{c}-0.865^{* * *} \\
(0.28)\end{array}$ & $\begin{array}{c}-1.564^{* * *} \\
(0.22)\end{array}$ & $\begin{array}{c}-0.968^{* *} \\
(0.38)\end{array}$ \\
\hline After Paris * Conservative & & $\begin{array}{c}-1.645^{* * *} \\
(0.44)\end{array}$ & & $\begin{array}{c}-1.525^{* *} \\
(0.59)\end{array}$ \\
\hline After Paris * Muslim & & & $\begin{array}{l}-0.512 \\
(0.38)\end{array}$ & $\begin{array}{l}-0.413 \\
(0.43)\end{array}$ \\
\hline Conservative * Muslim & & & & $\begin{array}{l}0.235 \\
(0.58)\end{array}$ \\
\hline $\begin{array}{l}\text { After Paris * Conservative * } \\
\text { Muslim }\end{array}$ & & & & $\begin{array}{l}-0.263 \\
(0.88)\end{array}$ \\
\hline Constant & $\begin{array}{c}3.919^{* * *} \\
(0.18)\end{array}$ & $\begin{array}{c}3.670^{* * *} \\
(0.19)\end{array}$ & $\begin{array}{c}3.793^{* * *} \\
(0.20)\end{array}$ & $\begin{array}{c}3.583^{* * *} \\
(0.22)\end{array}$ \\
\hline Observations & 150 & 150 & 150 & 150 \\
\hline$R^{2}$ & 0.275 & 0.340 & 0.284 & 0.349 \\
\hline Adjusted $R^{2}$ & 0.260 & 0.322 & 0.264 & 0.317 \\
\hline
\end{tabular}


Table 7: Nested regression models of public office

\begin{tabular}{|c|c|c|c|c|}
\hline & Base Model & $\begin{array}{l}\text { Interaction: } \\
\text { PID }\end{array}$ & $\begin{array}{l}\text { Interaction: } \\
\text { Treatment }\end{array}$ & Full Model \\
\hline Round: After Paris & $\begin{array}{l}0.064 \\
(0.17)\end{array}$ & $\begin{array}{l}0.376^{*} \\
(0.19)\end{array}$ & $\begin{array}{l}0.228 \\
(0.23)\end{array}$ & $\begin{array}{l}0.458^{*} \\
(0.25)\end{array}$ \\
\hline Treatment: Muslim & $\begin{array}{l}0.065 \\
(0.17)\end{array}$ & $\begin{array}{l}0.067 \\
(0.16)\end{array}$ & $\begin{array}{l}0.278 \\
(0.25)\end{array}$ & $\begin{array}{l}0.125 \\
(0.31)\end{array}$ \\
\hline PID: Conservative & $\begin{array}{c}-1.261^{* * *} \\
(0.20)\end{array}$ & $\begin{array}{c}-0.704^{* * *} \\
(0.25)\end{array}$ & $\begin{array}{c}-1.260^{* * *} \\
(0.20)\end{array}$ & $\begin{array}{c}-0.888^{* * *} \\
(0.34)\end{array}$ \\
\hline After Paris * Conservative & & $\begin{array}{c}-1.307^{* * *} \\
(0.39)\end{array}$ & & $\begin{array}{c}-1.041^{*} \\
(0.53)\end{array}$ \\
\hline After Paris * Muslim & & & $\begin{array}{l}-0.374 \\
(0.34)\end{array}$ & $\begin{array}{l}-0.187 \\
(0.39)\end{array}$ \\
\hline Conservative * Muslim & & & & $\begin{array}{l}0.421 \\
(0.52)\end{array}$ \\
\hline $\begin{array}{l}\text { After Paris * Conservative * } \\
\text { Muslim }\end{array}$ & & & & $\begin{array}{l}-0.597 \\
(0.79)\end{array}$ \\
\hline Constant & $\begin{array}{c}4.264^{* * *} \\
(0.16)\end{array}$ & $\begin{array}{c}4.066^{* * *} \\
(0.17)\end{array}$ & $\begin{array}{c}4.173^{* * *} \\
(0.18)\end{array}$ & $\begin{array}{c}4.042^{* * *} \\
(0.20)\end{array}$ \\
\hline Observations & 150 & 150 & 150 & 150 \\
\hline$R^{2}$ & 0.230 & 0.285 & 0.236 & 0.295 \\
\hline Adjusted $R^{2}$ & 0.214 & 0.265 & 0.215 & 0.260 \\
\hline
\end{tabular}




\section{Robustness Check - Results for complete sample}

Table 8: Full regression models for complete sample (robustness check)

\begin{tabular}{|c|c|c|c|c|}
\hline & Feelings & Social Welfare & Voting & Public Office \\
\hline Round: After Paris & $\begin{array}{l}3.960 \\
(4.35)\end{array}$ & $\begin{array}{l}0.100 \\
(0.16)\end{array}$ & $\begin{array}{l}0.341 \\
(0.30)\end{array}$ & $\begin{array}{l}0.246 \\
(0.25)\end{array}$ \\
\hline Treatment: Muslim & $\begin{array}{l}1.139 \\
(5.72)\end{array}$ & $\begin{array}{l}0.014 \\
(0.21)\end{array}$ & $\begin{array}{l}0.250 \\
(0.40)\end{array}$ & $\begin{array}{l}0.125 \\
(0.33)\end{array}$ \\
\hline PID: Conservative & $\begin{array}{l}-7.186 \\
(6.32)\end{array}$ & $\begin{array}{c}-0.708^{* * *} \\
(0.23)\end{array}$ & $\begin{array}{c}-0.968^{* *} \\
(0.44)\end{array}$ & $\begin{array}{c}-0.888^{* *} \\
(0.36)\end{array}$ \\
\hline After Paris * Conservative & $\begin{array}{l}0.476 \\
(9.07)\end{array}$ & $\begin{array}{l}-0.212 \\
(0.33)\end{array}$ & $\begin{array}{c}-1.290^{* *} \\
(0.63)\end{array}$ & $\begin{array}{c}-1.067^{* *} \\
(0.52)\end{array}$ \\
\hline After Paris * Muslim & $\begin{array}{l}-6.253 \\
(6.57)\end{array}$ & $\begin{array}{c}-0.0850 \\
(0.24)\end{array}$ & $\begin{array}{l}-0.322 \\
(0.46)\end{array}$ & $\begin{array}{l}-0.167 \\
(0.38)\end{array}$ \\
\hline Conservative * Muslim & $\begin{array}{l}4.030 \\
(9.61)\end{array}$ & $\begin{array}{l}0.386 \\
(0.35)\end{array}$ & $\begin{array}{l}0.235 \\
(0.67)\end{array}$ & $\begin{array}{l}0.421 \\
(0.55)\end{array}$ \\
\hline $\begin{array}{l}\text { After Paris * Conservative * } \\
\text { Muslim }\end{array}$ & $\begin{array}{l}-20.31 \\
(13.07)\end{array}$ & $\begin{array}{c}-1.022^{* *} \\
(0.48)\end{array}$ & $\begin{array}{l}0.171 \\
(0.91)\end{array}$ & $\begin{array}{l}0.015 \\
(0.75)\end{array}$ \\
\hline Constant & $\begin{array}{c}74.417^{* * *} \\
(3.75) \\
\end{array}$ & $\begin{array}{l}4.708^{* * *} \\
(0.14)\end{array}$ & $\begin{array}{l}3.583^{* * *} \\
(0.26)\end{array}$ & $\begin{array}{c}4.042^{* * *} \\
(0.21)\end{array}$ \\
\hline $\begin{array}{l}\text { Observations } \\
R^{2}\end{array}$ & $\begin{array}{c}215 \\
0.105\end{array}$ & $\begin{array}{c}214 \\
0.279\end{array}$ & $\begin{array}{c}212 \\
0.209\end{array}$ & $\begin{array}{c}212 \\
0.217\end{array}$ \\
\hline
\end{tabular}


Figure 3: Predicted values for control sample (robustness check)

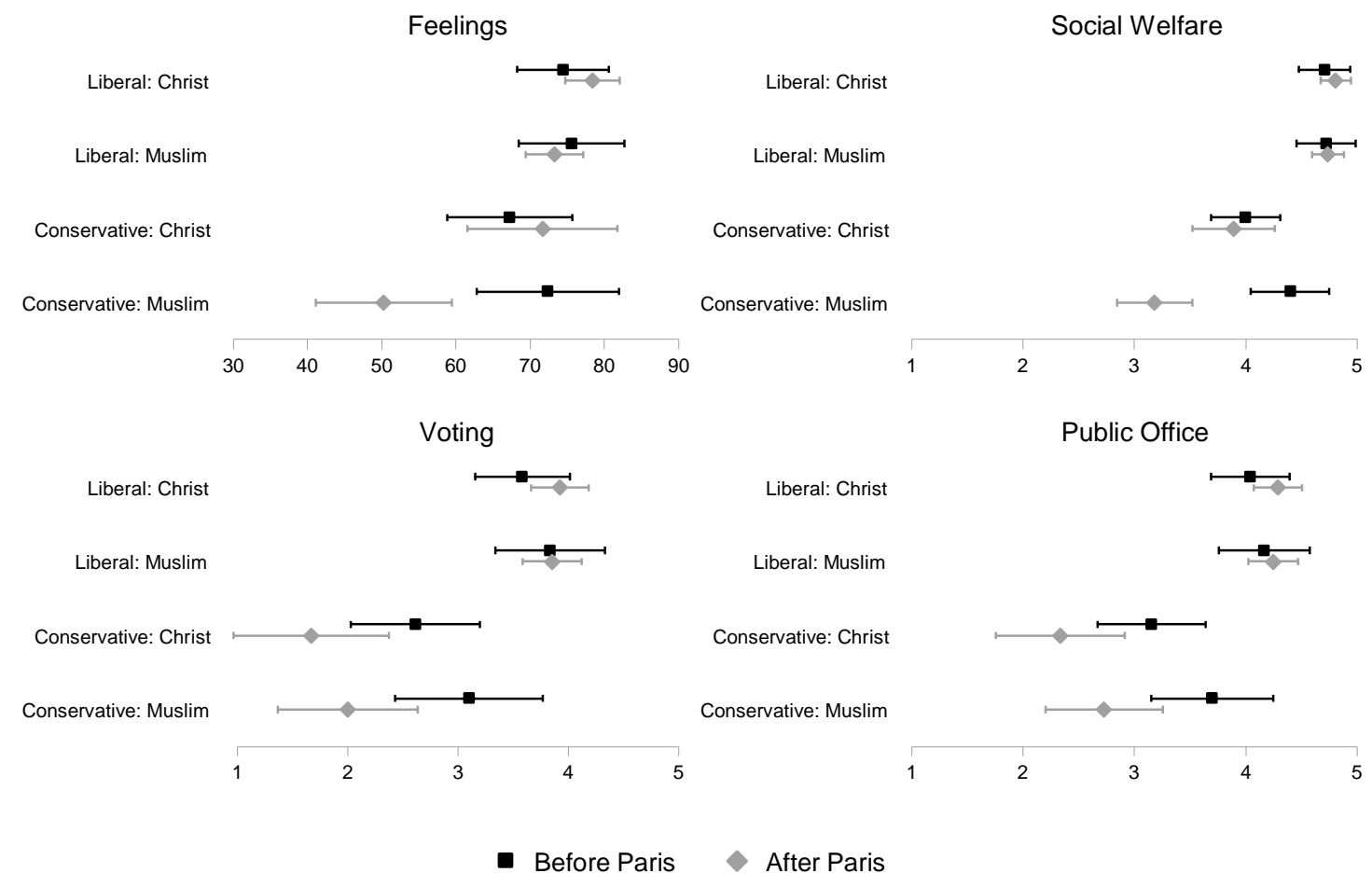

Shown are mean values with $90 \%$ confidence intervals based on regression analyses. 


\section{Motivation of respondents and composition of sample}

Table 9: Motivation of respondents and composition

\begin{tabular}{|l|l|c|c|c|c|}
\hline Political Interest & Subgroup & N & Mean & SD & 90\% CI \\
\hline $\begin{array}{l}\text { Bamberg vs. Non-Bamberg students: } \\
\text { Second round (n=86) }\end{array}$ & Non-Bamberg & 44 & 1.386 & 0.784 & $1.190 ; 1.583$ \\
\cline { 2 - 6 } & Bamberg & 42 & 1.429 & 0.630 & $1.267 ; 1.590$ \\
\hline $\begin{array}{l}\text { Only Bamberg students: } \\
\text { Both rounds (n=107) }\end{array}$ & Before Paris & 65 & 1.585 & 0.748 & $1.431 ; 1.739$ \\
\cline { 2 - 6 } & After Paris & 42 & 1.429 & 0.630 & $1.267 ; 1.590$ \\
\hline
\end{tabular}

\begin{tabular}{|l|l|c|c|c|c|}
\hline Threat Perception - Terrorism & Subgroup & N & Mean & SD & 90\% CI \\
\hline $\begin{array}{l}\text { Bamberg vs. Non-Bamberg students: } \\
\text { Second round (n=86) }\end{array}$ & Non-Bamberg & 44 & 3.477 & 1.389 & $3.129 ; 3.826$ \\
\cline { 2 - 6 } & Bamberg & 42 & 3.238 & 1.679 & $2.807 ; 3.669$ \\
\hline $\begin{array}{l}\text { Only Bamberg students: } \\
\text { Both rounds (n=107) }\end{array}$ & Before Paris & 65 & 3.569 & 1.704 & $3.218 ; 3.920$ \\
\cline { 2 - 6 } & After Paris & 42 & 3.238 & 1.679 & $2.807 ; 3.669$ \\
\hline
\end{tabular}

\begin{tabular}{|l|l|c|c|c|c|}
\hline Threat Perception - Refugees & Subgroup & N & Mean & SD & 90\% CI \\
\hline $\begin{array}{l}\text { Bamberg vs. Non-Bamberg students: } \\
\text { Second round (n=86) }\end{array}$ & Non-Bamberg & 44 & 1.227 & 0.424 & $1.121 ; 1.334$ \\
\cline { 2 - 7 } & Bamberg & 42 & 2.167 & 1.696 & $1.732 ; 2.602$ \\
\hline $\begin{array}{l}\text { Only Bamberg students: } \\
\text { Both rounds (n=107) }\end{array}$ & Before Paris & 65 & 1.954 & 1.316 & $1.431 ; 1.739$ \\
\cline { 2 - 6 } & After Paris & 42 & 2.167 & 1.696 & $1.732 ; 2.602$ \\
\hline
\end{tabular}

Question wording (German):

Wie stark interessieren Sie sich im Allgemeinen für Politik?

1 - sehr stark; 2 - eher stark; 3 - mittelmäßig; 4 - weniger stark; 5 - überhaupt nicht

Question wording (English):

In general, how interested are you in politics?

1 - very interested; 2 - rather interested; 3 - somewhat; 4 - rather not interested; 5 -not interested at all

Question wording (German):

Inwieweit fühlen Sie sich von den folgenden Aspekten (Terrorismus/Flüchtlinge) bedroht?

1 - überhaupt nicht bedroht; 4 - teils/teils; 7 - sehr bedroht

Question wording (English):

To what extend do you feel threatened by the following aspects (terrorism/refugees)?

1 -not threatened at all; 4 - somewhat; 7 - very threatened 


\section{References}

Bischof Daniel (2017) New graphic schemes for Stata: plotplain and plottig. Stata Journal 17(3): 748759.

Bonanno GA and Jost JT (2006) Conservative Shift Among High-Exposure Survivors of the September 11th Terrorist Attacks. Basic and Applied Social Psychology 28(4): 311-323.

Boomgaarden HG and Vliegenthart R (2007) Explaining the rise of anti-immigrant parties: The role of news media content. Electoral Studies 26(2): 404-417.

Boomgaarden HG and Vliegenthart R (2009) How news content influences anti-immigration attitudes: Germany, 1993-2005. European Journal of Political Research 48(4): 516-542.

Brooks C and Manza J (2013) Whose Rights? Counterterrorism and the Dark Side of American Public Opinion. New York: Russell Sage Foundation.

Campbell A, Converse PE, Miller WE and Stokes DE (1960) The American Voter. New York: Wiley.

Canetti-Nisim D, Halperin E, Sharvit K and Hobfoll SE (2009) A New Stress-Based Model of Political Extremism: Personal Exposure to Terrorism, Psychological Distress, and Exclusionist Political Attitudes. Journal of Conflict Resolution 53(3): 363-389.

Caprara GV, Schwartz S, Capanna C, Vecchione M and Barbaranelli C (2006) Personality and Politics: Values, Traits, and Political Choice. Political Psychology 27(1): 1-28.

Citrin J and Sides J (2008) Immigration and the Imagined Community in Europe and the United States. Political Studies 56(1): 33-56.

Davis DW (2007) Negative Liberty: Public Opinion and the Terrorist Attacks on America. New York: Russell Sage Foundation.

Dinesen PT, Klemmensen R and Nørgaard AS (2016) Attitudes Toward Immigration: The Role of Personal Predispositions. Political Psychology 37(1): 55-72.

Dolezal M, Helbling M and Hutter S (2010) Debating Islam in Austria, Germany and Switzerland: Ethnic Citizenship, Church-State Relations and Right-Wing Populism. West European Politics 33(2): 171-190.

Dostal JM (2015) The Pegida Movement and German Political Culture: Is Right-Wing Populism Here to Stay? The Political Quarterly 86(4): 523-531.

Druckman JN and Kam CD (2011) Students as Experimental Participants: A Defense of the 'Narrow Data Base'. In: Druckman JN, Green DP, Kuklinski JH and Lupia A (eds) Cambridge Handbook of Experimental Political Science. New York: Cambridge University Press, pp. 41-57.

Duckitt J and Fisher K (2003) The Impact of Social Threat on Worldview and Ideological Attitudes. Political Psychology 24(1): 199-222.

Echebarria-Echabe A and Fernández-Guede E (2006) Effects of terrorism on attitudes and ideological orientation. European Journal of Social Psychology 36(2): 259-265.

Eysenck MW (1992) Anxiety: The Cognitve Perspective. London: Lawrence Erlbaum.

Fischhoff B, Gonzalez RM, Small DA and Lerner JS (2003) Judged Terror Risk and Proximity to the World Trade Center. Journal of Risk and Uncertainty 26(2/3): 137-151.

Flanagan SC and Lee A (2003) The New Politics, Culture Wars, and The Authoritarian-Libertarian Value Change in Advanced Industrial Democracies. Comparative Political Studies 36(3): 235270.

Goren P (2005) Party Identification and Core Political Values. American Journal of Political Science 49(4): 882-897. 
Greenberg J, Pyszczynski T and Solomon S (1986) The causes and consequences of a need for selfesteem: A terror management theory. In: Baumeister RF (ed.) Public Self and Private Self. New York: Springer, pp. 189-212.

Häusler A (2016) Die Alternative für Deutschland: Programmatik, Entwicklung und politische Verortung. Wiesbaden: Springer VS.

Helbling M and Traunmüller R (2016) How State Support of Religion Shapes Attitudes Toward Muslim Immigrants. New Evidence From a Sub-National Comparison. Comparative Political Studies 49(3): 391-424.

Hobfoll SE, Canetti-Nisim D, Johnson RJ, Palmieri PA, Varley JD and Galea S (2008) The association of exposure, risk, and resiliency factors with PTSD among Jews and Arabs exposed to repeated acts of terrorism in Israel. Journal of traumatic stress 21(1): 9-21.

Hopkins DJ (2010) Politicized Places: Explaining Where and When Immigrants Provoke Local Opposition. American Political Science Review 104(1): 40-60.

Hopkins DJ (2011) National Debates, Local Responses: The Origins of Local Concern about Immigration in Britain and the United States. British Journal of Political Science 41(3): 499-524.

Huddy L and Feldman S (2011) Americans respond politically to 9/11. Understanding the Impact of the Terrorist Attacks and Their Aftermath. American Psychologist 66(6): 455-467.

Huddy L, Feldman S, Taber C and Lahav G (2005) Threat, Anxiety, and Support of Antiterrorism Policies. American Journal of Political Science 49(3): 593-608.

Huddy L, Khatib N and Capelos T (2002) The Polls-Trends. Reactions to the Terrorist Attacks of September 11, 2001. Public Opinion Quarterly 66(3): 418-450.

Iser J and Schmidt P (2003) Gefährliche Werte? Was Tradition und Konformität anrichten können. In: Heitmeyer W (ed.) Deutsche Zustände. Folge 2. Frankfurt/Main: Suhrkamp, pp. 61-77.

Jost JT and Banaji MR (1994) The role of stereotyping in system-justification and the production of false consciousness. British Journal of Social Psychology 33(1): 1-27.

Jost JT, Glaser J, Kruglanski AW and Sulloway FJ (2003) Political Conservatism as Motivated Social Cognition. Psychological Bulletin 129(3): 339-375.

Kam CD and Kinder DR (2007) Terror and Ethnocentrism: Foundations of American Support for the War on Terrorism. Journal of Politics 69(2): 320-338.

Kam CD, Wilking JR and Zechmeister EJ (2007) Beyond the "Narrow Data Base": Another Convenience Sample for Experimental Research. Political Behavior 29(4): 415-440.

Kearns EM, Betus A and Lemieux A (2017) Why Do Some Terrorist Attacks Receive More Media Attention Than Others? Available at: https://ssrn.com/abstract=2928138.

Kriesi H, Grande E, Dolezal M, Helbling M, Höglinger D, Hutter S, et al. (2012) Political Conflict in Western Europe. Cambridge: Cambridge University Press.

Kruglanski AW (1989) Lay epistemics and human knowledge: Cognitive and motivational basis. New York: Plenum.

Lazarsfeld PF, Berelson B and Gaudet H (1944) The People's Choice. How the Voter Makes Up his Mind in a Presidential Campaign. New York: Duell, Sloan and Pearce.

Legewie J (2013) Terrorist Events and Attitudes toward Immigrants: A Natural Experiment. American Journal of Sociology 118(5): 1199-1245.

Lerner JS and Keltner D (2001) Fear, Anger, and Risk. Journal of Personality and Social Psychology 81(1): 146-159.

Lodge M, McGraw KM and Stroh P (1989) An Impression-Driven Model of Candidate Evaluation. The American Political Science Review 83(2): 399-419.

Lupia A and Menning JO (2009) When Can Politicians Scare Citizens Into Supporting Bad Policies? American Journal of Political Science 53(1): 90-106.

Malhotra N and Popp E (2012) Bridging Partisan Divisions over Antiterrorism Policies. The Role of Threat Perceptions. Political Research Quarterly 65(1): 34-47. 
Merolla JL and Zechmeister EJ (2009) Democracy at Risk: How Terrorist Threat Affect the Public. Chicago: University of Chicago Press.

Morrison KR, Fast NJ and Ybarra O (2009) Group status, perceptions of threat, and support for social inequality. Journal of Experimental Social Psychology 45(1): 204-210.

Mudde C (2007) Populist Radical Right Parties in Europe. New York: Cambridge University Press.

Peffley M, Hutchison ML and Shamir M (2015) The Impact of Persistent Terrorism on Political Tolerance: Israel, 1980 to 2011. American Political Science Review 109(4): 817-832.

Piazza JA (2015) Terrorist Suspect Religious Identity and Public Support for Harsh Interrogation and Detention Practices. Political Psychology 36(6): 667-690.

Rattinger H, Schoen H, Endres F, Jungkunz S, Mader M and Pötzschke J (2016) Old Friends in Troubled Waters: Policy Principles, Elites, and U.S.-German Relations at the Citizen Level after the Cold War. Baden-Baden: Nomos.

Schoen H (2006) Der demokratische Musterbürger als Normalfall? Kognitionspsychologische Einblicke in die black box politischer Meinungsbildung. Politische Vierteljahresschrift 47(1): 89101.

Schoen H and Schumann S (2007) Personality Traits, Partisan Attitudes, and Voting Behavior. Evidence from Germany. Political Psychology 28(4): 471-498.

Schwartz SH, Caprara GV, Vecchione M, Bain P, Bianchi G, Caprara MG, et al. (2014) Basic Personal Values Underlie and Give Coherence to Political Values: A Cross National Study in 15 Countries. Political Behavior 36(4): 899-930.

Sobolewska M, Ford R and Sniderman P (2016) Democratic resilience and liberal mobilisation in the face of terrorist threat. Natural and survey experiment. Paper presented at the APSA conference, Philadelphia, September 1-4.

Spilerman S and Stecklov G (2009) Societal Responses to Terrorist Attacks. Annual Review of Sociology 35(1): 167-189.

Stephan WG and Stephan CW (2000) An integrated threat theory of prejudice. In: Oskamp S (ed.) Reducing Prejudice and Discrimination. Mahwah, NJ: Lawrence Erlbaum, pp. 23-45.

Vecchione M, Caprara G, Schoen H, Castro JLG and Schwartz SH (2012) The role of personal values and basic traits in perceptions of the consequences of immigration: a three-nation study. British Journal of Psychology 103(3): 359-377.

Walgrave S and Swert K de (2004) The Making of the (Issues of the) Vlaams Blok. Political Communication 21(4): 479-500.

Westen D (2007) The Political Brain: The Role of Emotion in Deciding the Fate of the Nation. New York: Public Affairs.

Wilder DA (1993) The Role of Anxiety in Facilitating Stereotypic Judgments of Outgroup Behavior. In: Mackie DM and Hamilton DL (eds) Affect, Cognition and Stereotyping: Interactive Processes in Group Perception. San Diego: Academic Press, pp. 87-109.

Zaller J (1992) The Nature and Origins of Mass Opinion. New York: Cambridge University Press.

Zaller J and Feldman S (1992) A Simple Theory of the Survey Response: Answering Questions versus Revealing Preferences. American Journal of Political Science 36(3): 579-616. 